\title{
CLASSIFICATION OF BUILDING STONES OF THE FRANGOKASTELLO CASTLE, SFAKIA, CRETE
}

\author{
Cheimonas Th. ${ }^{1}$, Manoutsoglou E. ${ }^{1}$, Stavroulaki M. ${ }^{2}$ and Skoutelis N. ${ }^{2}$ \\ ${ }^{1}$ Technical University of Crete, School of Mineral Resources Engineering, Tectonic, Stratigraphy, \\ Environmental Geology Laboratory, University Campus, GR-73100 Chania, Greece, \\ ximonas91@hotmail.com; emanout@mred.tuc.gr \\ ${ }^{2}$ Technical University of Crete, School of Architectural Engineering, University Campus, GR- \\ 73100 Chania,Greece,mstavr@mred.tuc.gr;nskoutelis@isc.tuc.gr
}

\begin{abstract}
Frangokastello is a medieval castle which was built by the Venetians in 1371-74 in a narrow coastal zone at the southeastern part of the White Mountains, approximately 12 km east of Chora Sfakion. The region around Frangokastello characterized by a strong morphological relief, which was formed by activity of normal faults striking $E-W, N N E-$ $S S W$ and NNW-SSE. The region of interest has covered at the surface from sequences mainly marine sediments of Tortonian, Low Pliocene and Lower Pleistocene.

From the Middle Pleistocene multiple alluvial fans have been cover the alpine basement of the region which consists from metamorphic rocks of the Plattenkalk Group, Trypali Unit and Phyllite Quartzite Series as well the youngest in age formations. Rounded and angular fragments of rock materials from alpine and post alpine formations transported and deposited within the various parts of alluvial fan which had deposited over the Frangokastello formation, constituted the building stones for the construction of the castle. The microclimate of the region and the intense tectonic activity associated with relatively high rates of uplift of the tectonic segments in the region, has critically affect not only the static of the castle but also the resistance from the weathering of building stones after physical dismantling large parts of the binding cement and surface from outer wall. On the basis of the above, the objective of this work is initially the collection of bibliographic data related to the stratigraphy and tectonics of the region. The results obtained, combined with the results from counting and statistical processing of various lithological types of building materials of the castle can be considered input data to form static models, in the framework of proposals for maintenance and restoration of the monument.
\end{abstract}

Keywords: Alluvial fan, building materials, restoration, monument.

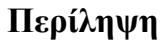

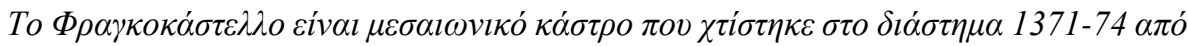

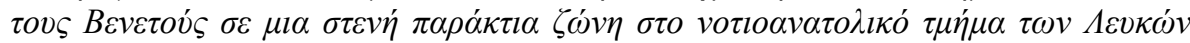

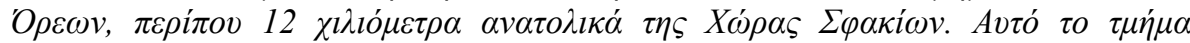

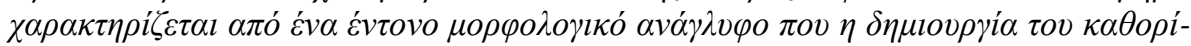

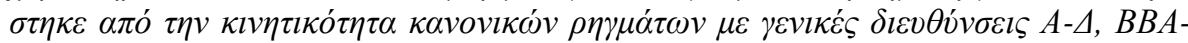

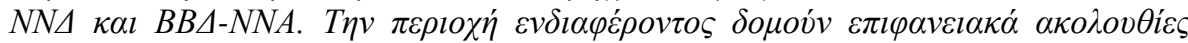

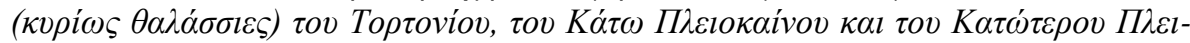

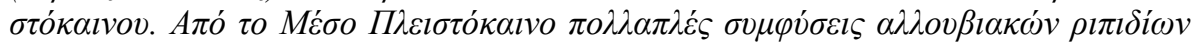




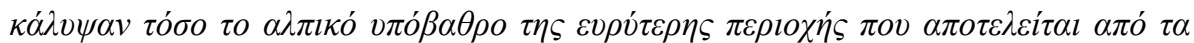
$\mu \varepsilon \tau \alpha \mu о \rho \varphi \omega \mu \varepsilon ́ v \alpha ~ \pi \varepsilon \tau \rho \omega ́ \mu \alpha \tau \alpha ~ \tau \eta \varsigma ~ O \mu \alpha ́ \delta \alpha \varsigma ~ \tau \omega v ~ \Pi \lambda \alpha \kappa \omega \delta \omega ́ v ~ A \sigma \beta \varepsilon \sigma \tau o \lambda i \theta \omega v, ~ \tau \eta \varsigma ~ \varepsilon v o ́ \tau \eta \tau \alpha \varsigma$

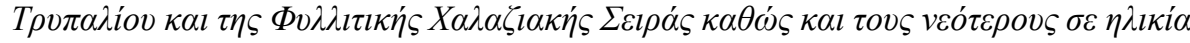

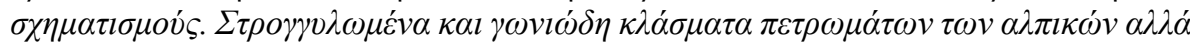

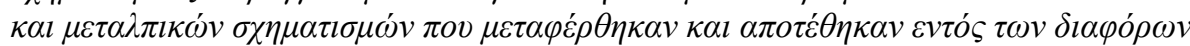

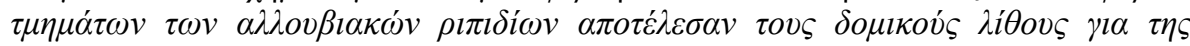

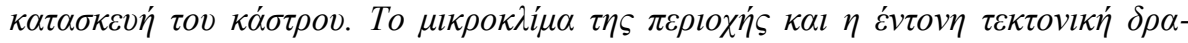

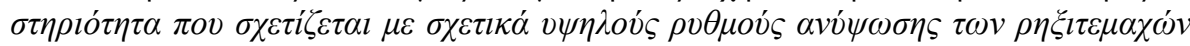

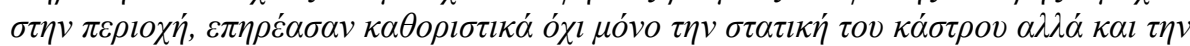

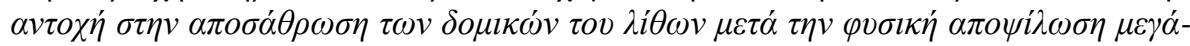

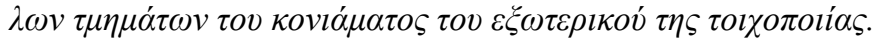

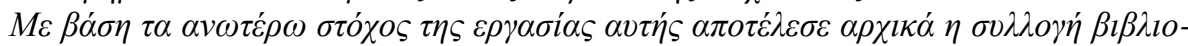

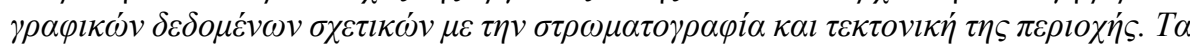

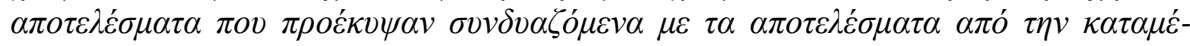

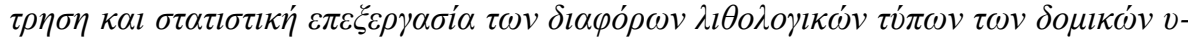

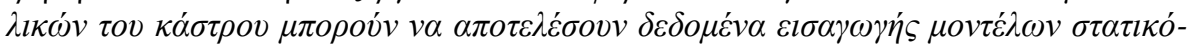

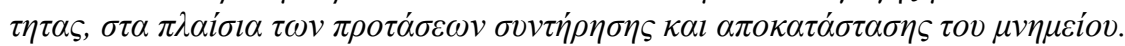

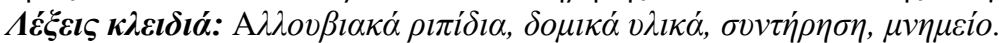

\section{Introduction}

The Venetian castle of Frangokastello is built in 1371-1374 in Sfakia region, a narrow coastal zone in the south-eastern part of the White Mountains and was the basis of a Venetian military force, which essentially never settled in the castle. There have been many alterations to the Frangokastello, particularly in the period 1866-1869 by Mustafa Naili; however in its current shape does not show significant differences compared with the representations of the Venetian drawings. In this sense it follows the old fortification perceptions, before the prevalence of "bastion system", which will arrive in Crete before the mid-16th century. The castle is a rectangular building with vertical walls and four-sided towers at four corners, from which the southwest is much higher. The towers and the walls have on their edges jagged battlements. The main entrance was located south and its current form is a reconstruction of the 19th century. Another entrance has been opened in the east.

The three small towers are preserved with several phases of reconstruction, mainly on floors. From the preserved old evidence suggests that the ground floor was vaulted and the upper part rebuilt many times with mezzanine and gravel roof on the first floor. The largest tower maintained by smaller operations. This tower was a special defensive element of the fort, as was able to accommodate larger number of combatants and because of its location there was a greater visibility.

The ground-floor buildings held in the inner courtyard are reconstructed on recently on the remains of the walls of the last building phase. It is adjacent rectangular spaces destined to house the soldiers and for other uses (warehouses, kitchens, etc.).

When large structures such a castle exist in seismically unstable regions, the activity of faults or fault systems in and around the sites must be assessed. The walls of the Fragokastello castle are crossed by many cracks. There are various possible causes for these damages. The maintenance and restoration of damages represent a special challenge at the present time as well. Maintenance and restoration is a common problem of historical stone structures since they are under protection for their historical value. Building stones have widespread use in historic monuments which may provide unlimited durability if adequate conservation methods are applied; however it is well known that the great diversity of their nature often impairs the choice of the most suitable maintenance procedures. To control the stability and to verify the load-bearing capacity of the castle there are several modeling methods from the simple approximate calculations to the difficult numerical methods. With the ultimate goal to investigate the geotechnical conditions of the castle, aim of the 
present work is the characterization due simple statistical analysis various lithologies of the building stones of the masonry (Odysseus, 2016).

\section{Geological setting}

The Hellenides as part of the Alpine-Himalayan Orogenic Belt have been interpreted traditionally in terms of north directed convergence between Africa and Europe. The island of Crete is located north of the Hellenic trench and is a complex horst structure within the present forearc in the upper plate, on top of the shallow portion of the active Eastern Mediterranean collision zone. The island of Crete is one of the most seismically active area in the eastern Mediterranean. Tectonic uplift started since about 0.6 Ma as documented by Middle-Late Pleistocene marine terraces and Holocene raised notches along the coasts of the island and, on land. Normal faults typically consist of 4-30$\mathrm{km}$-long dip slip segments locally organised in more complex fault zones. They separate carbonate and/or metamorphic basement, in the footwall block, from Neogene, but especially loose to poorly consolidated alluvial and colluvial materials on the top of the hangingwall. All these faults show clear evidences of recent re-activations and trend parallel to two principal directions: WNW-ESE and NNE-SSW (Caputo et al., 2010 and references therein). The activity of these faults created the Sfakian piedmont, a $24 \mathrm{~km}$-long and 1.5 to $2.5 \mathrm{~km}$-wide east-west trending coastal plain. The northern margins of the coastal plain are defined by the Sfakia fault zone that cuts across the lower slopes of the Lefka Ori mountain range. The footwall area of the Sfakia fault comprises mainly marble of the Plattenkalk Group and Trypali Unit. The western hangingwall area is dominated by alluvial fans along the mountain front. To the east the existence of phyllites on the hangingwall area of the Sfakia fault indicates significant vertical displacement (throw) of this fault. A complicating factor for calculating throws is the existence of the Fragokastello normal fault (Skourtsos et al., 2007) which runs oblique to the Sfakia fault and terminates against it (Figure 1) (Nemec and Postma, 1993; Tsimi et al., 2007; Skourtsos et al., 2007; Pope et al., 2008 ).

The coastal area between Chora Sfakion and Skaloti are covered by Neogene to Lower Pleistocene marine deposits (IGME, 1987) partly covered by Middle (?) Pleistocene -Holocene alluvial fans. These post-alpine deposits overlie the alpine basement with an angular unconfonnity. Three main marine sequences can be distinguished based on lithostratigraphy mapping. In stratigraphic order these are: the Skaloti Formation, the Chora Sfakion Formation and the Frangokastelo Formation. The Frangokastelo Formation occupies the central part of the coastal zone (Skourtsos et al., 2007). The stratigraphic position of the formation is uncertain. It has been tentatively placed in the Middle Pliocene by Meulenkamp (1969) and the same outcrops were dated Late Pliocene by van Hinsbergen and Meulenkamp (2006). After Skourtsos et al. (2007) the Frangokastello Formation are much younger than previous age estimates. Using calcareous nannofossils an Early Pleistocene age for the Frangokastello Formation was determined.

As shown in Figure 2, in a position south of the castle exists a sequence that comprises of limestones with pebbles, both rounded and angular, with intercalations of sandstones, clays and clayed marls, such as the sequence reported by Meulenkamp (1969) in the village of Agios Nektarios. 


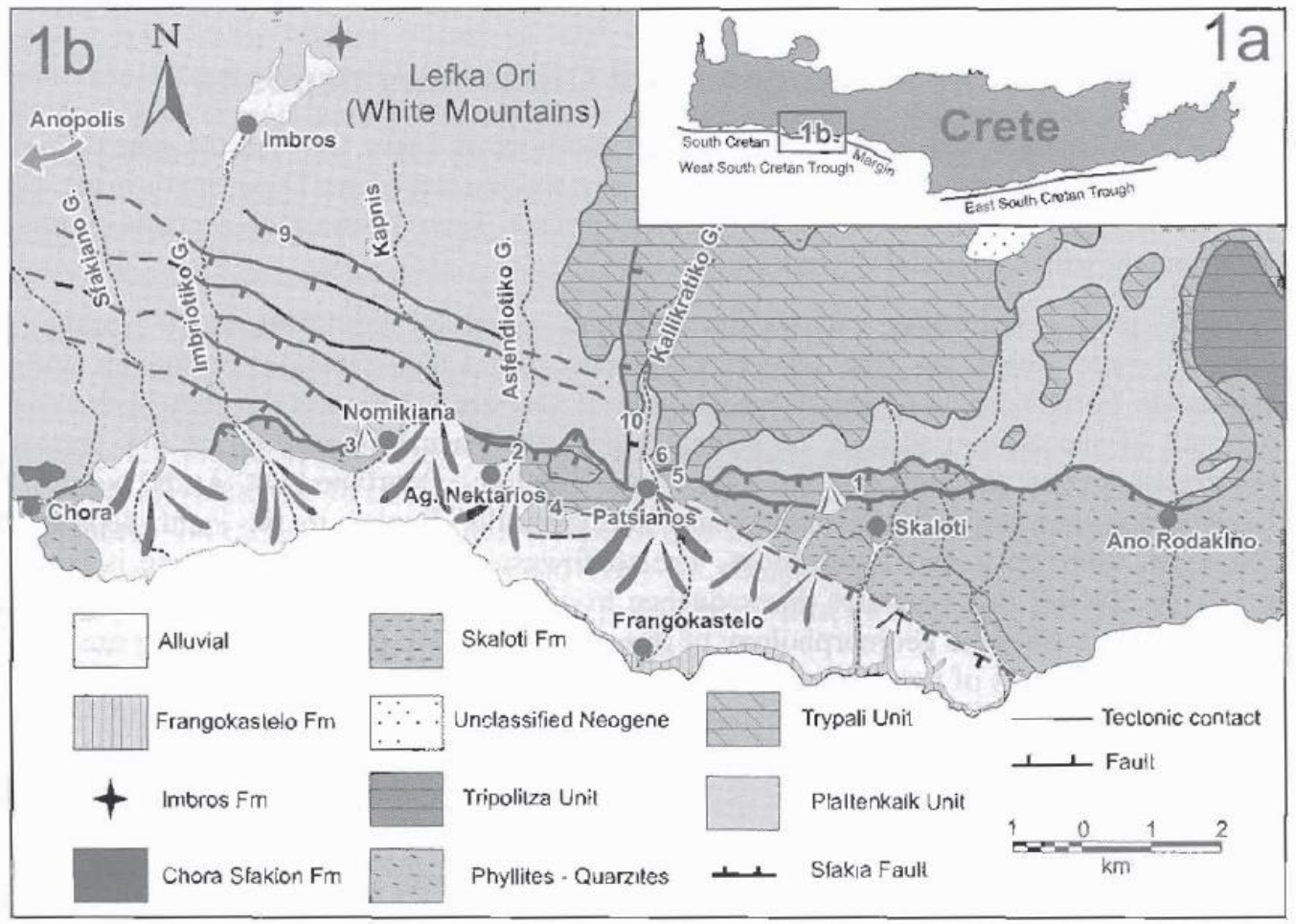

Figure 1 - a) Geological sketch map of the study area modified from I.G.M.E. (1982, 1987). b) The Sfakia coastal zone represents an onshore segment of the South Cretan margin (after Skourtsos et al., 2007, modified from Alves et al., 2007).

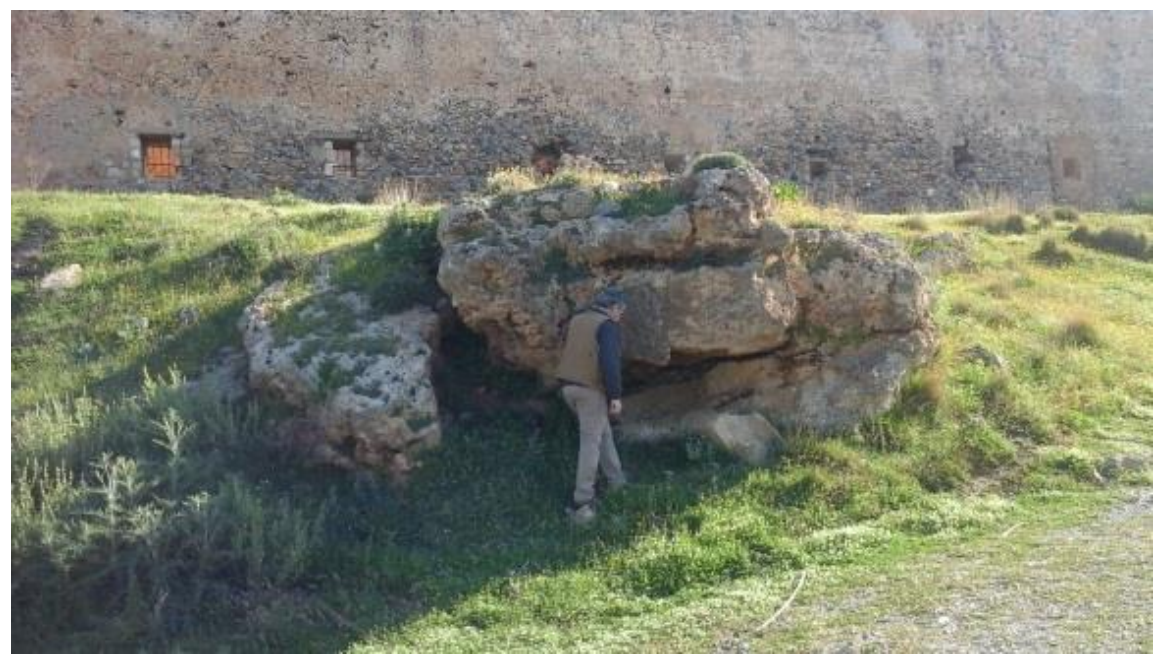

Figure 2 - Section at the cliff south of the castle: transition of clastic sedimentation (sandstones, microconglometates with intercalations of clays and clayed marls) to limestones with pebbles and bioclastic limestones.

\section{Materials and Methods}

The masonry of Frangokastello is composed of rocks with various lithologies including different forms of carbonate and clastic sediments. The materials are originated from the vicinity of the 
building, from the nearby alluvial fan deposits. Sedimentary rocks such as sandstones and (micro) conglomerates were also identified. Several forms of stones are used as masonry materials. Besides cut blocks of marble of the Plattenkalk Group, rounded cobbles of (meta)dolomites of the Trypali Unit form also a significant part of the masonry walls. Porous limestone has wide variety in fabric, porosity and poresize distribution (Figure 3 ).

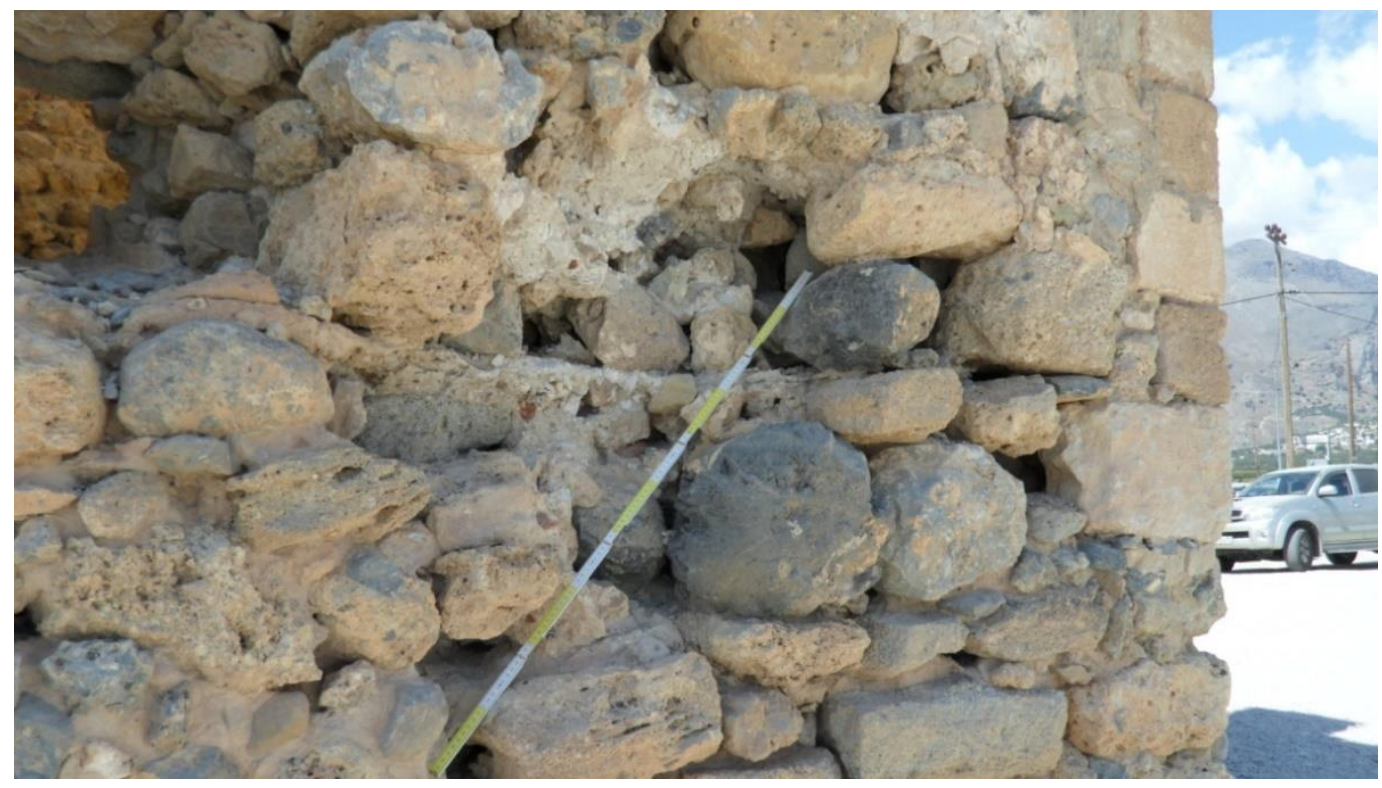

Figure 3 - Various rock types in the masonry walls.

Aiming at a statistical quantification of the various lithological types of the rock fragments that were used to construction of the castle, we performed the following steps:

Firstly, we choose an appropriate area, i.e. the southern wall of the castle, where the mortar coating has been eroded. As a result of the erosion the building rocks are visible and measurable. Thus, it was reliable for the counting of rock fragments and subsequently for the statistical analysis on these constructions materials. In particular, we used a high resolution image (scale 1:100) of the south wall (Figure 4), in order to imprint the various lithologies of the building stones.

Secondly, image processing was utilized by AutoCAD software as follows:

(i) We designed the outlines of building stones in a selected wall surface with dimensions $22,67 \times 2,19 \mathrm{~m}$, which is situated about $30 \mathrm{~cm}$ above the ground surface, so that it is easy to have access to the area in order to identify and count the rocks (Figure 4 ).

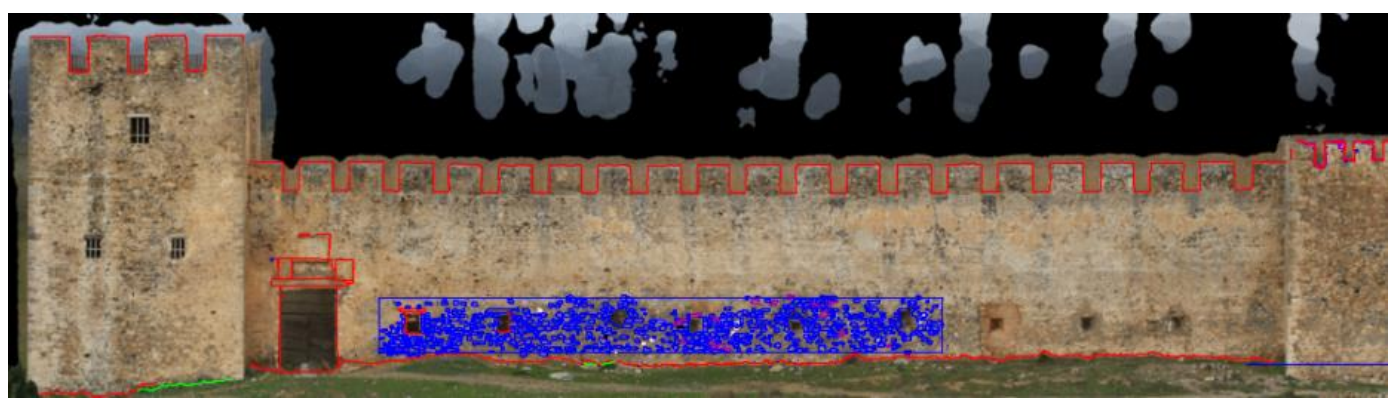

Figure 4 - The south wall designed with the outlines of the building stones of various rock lithotypes in selected area with dimensions $22,67 \times 2,19 \mathrm{~m}$. 
(ii) We printed in scale 1:100 on paper A0, the image of the surface including all visible and measurable outlines of the building stones.

(iii) In situ observations considering the lithology led to the identification and counting of each bui lding stone within this area. Different lithologies highlighted with different colours.

(iv) Due to discrimination problems of two cement types, such as coating and binding cement, we performed a simple calculation using AutoCAD software. Specifically, the different lithology of the building stones (e.g. dolomites, sandstones), as well as the two cement types were imprinted in the paper, and converted manually with the aid of AutoCAD in their corresponding colours. The generated AutoCAD electronic file allows further correlations and calculations.

Figure 5 illustrates the final result of the differentially coloured lithologies of building stones within the selected surface on the southern wall of the castle. In the same surface, there are two smaller areas, in which the percentage of the binding cement was approximately calculated. The selection of surfaces A and B was done with the criterion that within these there are not smaller in size building stones which could not be registered. The total area of each surface is in square meters $\left(\mathrm{m}^{2}\right)$. The percentage participation of the binding cement in relation to the total surface area of each surface A and B calculated indirectly and automatically with the command AREA in software AutoCAD. For the surface A coverage of the mortar is $0,32 \mathrm{~m}^{2}$ and $0,4 \mathrm{~m}^{2}$ for the surface $\mathrm{B}$. Therefore the percentage of the total surface area of the covered by the binding cement for surface A and B are $31.76 \%$ and $40.18 \%$ respectively, with a mean value at $35.95 \%$. The results for areas A and B are presented in detail on the following Table 1 . Table 2 shows the areas of building stones in $\mathrm{m}^{2}$ and percentages in $\%$.

Table 1 - Calculation table for Binding Cement.

\begin{tabular}{|c|c|c|c|c|}
\hline & \multicolumn{2}{|c|}{ Surface A } & \multicolumn{2}{c|}{ Surface B } \\
\cline { 2 - 5 } & $\begin{array}{c}\text { Surface } \\
\text { Area m }\end{array}$ & Percentage \% & $\begin{array}{c}\text { Surface } \\
\text { Area m }\end{array}$ & Percentage \% \\
\hline Sandstone & 0,0157 & 3.2 & 0 & 0 \\
\hline Dolomite & 0,0767 & 15,65 & 0.1086 & 22,16 \\
\hline Conglomerates & 0.0393 & 8,02 & 0.0485 & 9,9 \\
\hline Micro Conglomerates & 0,0892 & 18,2 & 0.0815 & 16,63 \\
\hline Biogenic Limestones & 0,1036 & 21,14 & 0,0253 & 5,16 \\
\hline Limestones & 0.0089 & 1,82 & 0.0259 & 5,29 \\
\hline Binding Cement & $\mathbf{0 , 1 5 5 5}$ & $\mathbf{3 1 , 7 3}$ & $\mathbf{0 , 1 9 6 9}$ & $\mathbf{4 0 , 1 8}$ \\
\hline 0,49 & 100 & & 0,49 & 100 \\
\hline
\end{tabular}




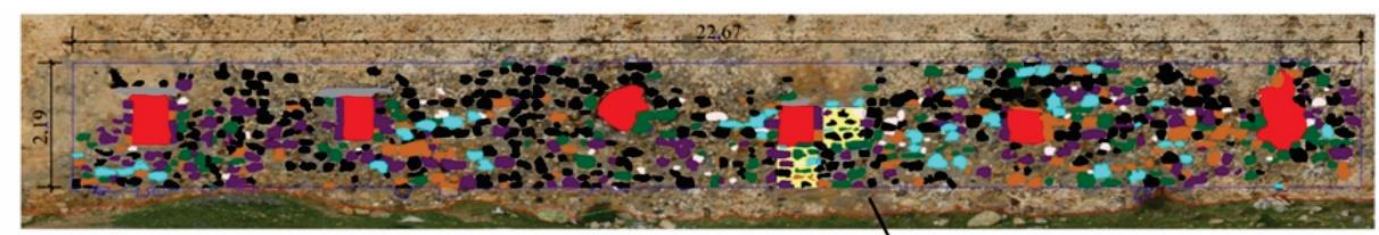

\section{Wall memorandum}

Gaps (loopholes)

Dolomites

Lintel

Microconglomerates

Conglomerates

Biogenic Limestones

Sandstones

Limestones

Binding cement

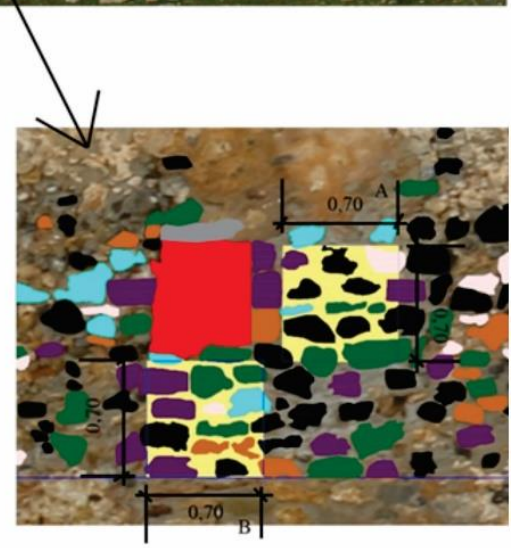

Surface A and B where calculated binding cement

Figure 5 - View of the surface in which were made the counts and calculations. The various lithological visualized in the above memorandum in different colours based on the colour scale. At the bottom right the surface $A$ and $B$ used as an approximation calculation of the binding cement.

On the selected surface, as described above, the superficially percentage occupied on the wall by various lithological building rocks types was calculated. The surface area of the parallelepiped is $49.70 \mathrm{~m}^{2}$. Besides of the different lithological building rock types this area contains gaps (loopholes), the lintel of the gaps (loopholes) and both types of cement, the binding cement and coating cement. Table 2 presents in detail the areas of each surface and the percentage in $49,70 \mathrm{~m}^{2}$ of the total area.

Table 2 - Cover surface and percentage of building rock types which used for construction of the castle

\begin{tabular}{|c|c|c|}
\hline Study Surface & ${\text { Surface Area } \mathbf{~ m}^{\mathbf{2}}}$ & Percentage $^{\mathbf{2}}$ \\
\hline Sandstone & 1,94 & 3,90 \\
\hline Dolomite & 6,98 & 14,04 \\
\hline Conglomerates & 1,38 & 2,77 \\
\hline Micro Conglomerates & 2,65 & 5,33 \\
\hline Biogenic Limestones & 3,50 & 7.04 \\
\hline Limestones & 0,45 & 0,91 \\
\hline gaps (loopholes) & 2,76 & 5,55 \\
\hline lintel of the gaps (loopholes) & 0,36 & 0,72 \\
\hline Coating cement + Binding Cement & 29,63 & 59,62 \\
\hline Total Surface & $\mathbf{4 9 , 7 0}$ & $\mathbf{1 0 0}$ \\
\hline
\end{tabular}


The surface area of the binding cement and coating cement were not calculated directly from software AutoCAD but indirectly by using the following formula.

Binding cement and coating cement $=$ total surface area- $($ sandstones surface area + dolomites surface area + conglomerates surface area + limestones surface area + micro conglomerates surface area + biogenic limestones surface area + gaps (loopholes) surface area + lintel of the gaps (loopholes) surface area namely:

Binding cement and coating cement $=49,70-(1,94+6,98+1,38+2,65+3,5+0,45+2,76+0,36)$ $=29,63 \mathrm{~m}^{2}$

According to the above table, we demonstrate that building rock type with the largest percentage on the wall surface area is black dolomite (metadolomite of Trypali Unit) with a percentage 14,04\%, followed by biogenic limestone with a percentage $7,04 \%$, micro conglomerates $5,33 \%$, sandstone $3,90 \%$, and conglomerates $2,77 \%$. A small percentage have gaps (loopholes) $0,72 \%$. The lowest percentage on the wall surface area belongs to the white limestone $0,91 \%$.

\section{Results}

Frangokastello is a Medieval castle which was built by the Venetians in 1371-74 in a narrow coastal zone at the southeastern part of the White Mountains characterized by a strong morphological relief. The creation of the relief was formed by mobility of normal faults with general striking E-W, NNESSW and NNW-SSE. These various tectonic blocks were uplifted several times. By the effect of intense tectonic activity the coastal plain was covered by multiple accretions of alluvial fans.

Frangokastello castle has been built on the biogenic limestone of Frangokastello formation. Rounded and angular fragments of resistant rock materials from alpine and post alpine formations transported and deposited within the various parts of alluvial fan, which had deposited over the Frangokastello formation. The coarse clastic fragments of both formations (Fragokastello and alluvial fans), constituted the building stones for the construction of the castle. By the statistical processing of measurements of various lithological rock types which were used for the construction of the castle, building rock types with the largest percentage on the wall surface area is black dolomite (metadolomite of Trypali Unit) with a percentage 14,04\%. Followed biogenic limestone with a percentage $7,04 \%$, micro conglomerates $5,33 \%$, sandstone by $3,90 \%$, conglomerates $2,77 \%$. A small percentage have gaps (loopholes) $0,72 \%$. The lowest percentage on the wall surface area belong by the white limestone (marble of the Plattenkalk Group) $0,91 \%$.

According to the above data we may conclude:

(i) Metadolomite of Trypali Unit has been preferred as building stones from all the Pre - alpine rocks which were transferred by alluvial fans to the coastline. The reason for this was that they combine a high durability, since they are metamorphosed, but simultaneously the external surface is not smooth like most other metacarbonate rocks (e.g. calcitic marble of the Trypali Unit and the Plattenkalk Group).

(ii) In contrast, the rest of the building stones do not have a high durability, but they have relatively high primary porosity which allows a better connection to the binding cement.

The results of the first statistical approach of rock fragments, which were the building blocks in the construction of the castle, can be input data for static and dynamic analysis models of the structural system, under the proposals maintenance and restoration of the monument. From the recording of various lithological types of rocks used to build the castle confirmed the fact of the coexistence of many different materials in the same construction and the different types of engagement of these materials in different parts of the structure. This fact is an important problem in the choice of the mechanical characteristics of the masonry to be used in the structural analysis. The choice of these parameters for monumental constructions requires research even if there is a possibility of measuring the mechanical characteristics of the individual materials which make up the walls. 


\section{Acknowledgments}

The authors wish to express thanks to the reviewers for their constructive comments and suggestions. We would like to thank especially Assistant Professor Partsinevelo Panagioti (Technical University of Crete) to provide high resolution image of the southern wall of the castle.

\section{References}

Alves, M.T., Lykousis, Y., Sakellariou, D., Alexandri, S. and Nomikou, P., 2007. Constraining the origin and evolution of confined turbidite systems: southern Cretan margin, Eastern Mediterranean Sea (34을 $\left.36^{\circ} \mathrm{N}\right)$, Geo-Marine Letters, 27, 41-61.

Caputo, R., Catalano, S., Monaco, C. Romagnoli G., Tortoric G. and Tortoric L., 2010. Active faulting on the island of Crete (Greece), Geophys. J. Int., 183, 111-126.

Institute of Geological and Mineral Exploration (I.G.M.E.), 1982. Geological map of Sellia (scale 1:50.000), Institute of Geological and Mineral Exploration, Athens.

Institute of Geological and Mineral Exploration (IGME), 1987. Geological map of Vrisses (scale 1:50.000), Institute of Geological and Mineral Exploration, Athens.

Nemec, W. and Postma, G., 1993. Quaternary alluvial fans in southwestern Crete: sedimentation processes and geomorphic evolution, Special Publication of the Association of Sedimentologists, 17, 235-276.

Meulenkamp, J.E., 1979. Field guide to the Neogene of Crete, Puplications of the Department of Geology \& Paleontology, Series A, No 32, 32 pp.

Odysseus, 2016. Available online at: http://odysseus.culture.gr/h/2/gh251.jsp?obj_id=16202.

Pope, R., Wilkinson, K., Skourtsos, E., Triantaphyllou, M. and Ferrier, G., 2008. Clarifying stages of alluvial fan evolution along the Sfakian piedmont, southern Crete: New evidence from analysis of post-incisive soils and OSL dating, Geomorphology, 94, 206-225.

Skourtsos, E., Pope, R. and Triantaphyllou, M.V., 2007. Tectono-sedimentary evolution and rates of tectonic uplift of the Sfakia coastal zone, southwestern Crete, Bulletin of the Geological Society of Greece, XXXX, 475-487.

Tsimi, C., Ganas, A., Ferrier, G., Drakatos, G., Pope, R.J. and Fassoulas, C., 2007. Morphotectonics of the Sfakia normal fault, South-western Crete, Greece, Proceedings of 8th Pan-Hellenic Geographical Conference, Athens, Greece, 2007 October 4-7, 186-194.

van Hinsbergen, D. and Meulenkamp, J., 2006. Neogene supradetachment basin development on Crete (Greece) during exhumation of the South Aegean core complex, Basin Research, 18, 103-124. 